\title{
Reviewing Practices: Engagement and the Middle School Band
}

\author{
Mundy Viar \\ Pleasant Hill Middle School, California, USA
}

\begin{abstract}
The instrumental music classroom, commonly called "the band" is comprised of students from all parts of a school population. Some may think or assume that band students are inherently engaged. However, engagement strategies to reach all students need to be reviewed, revisited, and modified, even in the ensemble-based class. Action steps to engage more students more often should be employed in the music room, modified as necessary, which means it is important to know what engagement in a classroom really means. Engagement is a changing state of being and is affected by different variables.
\end{abstract}

Keywords: band, engagement, Marzano, praxial music education, strategies

\section{Introduction}

In schools and school districts throughout the United States (U.S.), student engagement is a prominent goal toward achieving student success (West Branch Community Schools, 2017; Fredricks et al, 2011; Mt. Diablo Unified School District [MDUSD], n.d.). The author’s school lists among the weekly focus areas, “All classrooms should have in evidence students engaging in at least two of the four Cs-collaboration, creativity, communication, and critical thinking” (Pleasant Hill Middle School [PHMS] bulletin, March 7-10, 2017). This article discusses what is meant by engagement in education, why it is important, and what its relevance is to the instrumental music (band) room.

\section{Background}

The author is a credentialed instrumental music teacher in his 19th year of teaching students in public school music classes (generally called "the band" in this article). He has come to support the position that visual and performing arts classes, including the school bands, must coexist as both an artistic experience, with a focus on aesthetics and musicianship, and, importantly, as a utilitarian, academic support experience. The classes cannot exist as only one or the other, but as both, simultaneously. School communities are different and it seems natural that the interests in, purposes for, and implementation of school music classes and programs must reach, address, and support wide ranges of participants. While there is a common language around music performance education, the author does not believe that the bands in his community of Pleasant Hill, California, will be identical to the bands in Mountain View, Yreka, or Oakland, primarily because there are different groups of students, different demographics, and different interests from the communities at large. His guess is there are different academic needs around mathematics and reading that require different interventions, assessments, and management of time during the school day. As educators differentiate ways to engage students in the general academic classroom, so should music educators reflect on our approaches to engage the

Mundy Viar, Ph.D., teacher, Pleasant Hill Middle School (PHMS). 
band students differently, too.

The author has thought that students who participate in their school band are inherently engaged in learning, which is not necessarily so. As established through various agreements around engagement, addressed later in this article, it is more than just doing. In a traditional band setting, students sit in their sections and rehearse as a full ensemble, with various levels of enthusiasm and attentiveness, for the duration of the rehearsal, which also vary from school to school. The expectations and demands of teachers and students have changed, including the way content is delivered and received. The band, often long standing institutions within the institutions, should also be addressed in ways that encourage greater participation from the school population, and that means that the content delivery may look different, as well.

Kaplan (1966) was promoting this over 50 years ago. Music educators cannot sit by unconcernedly, during these times of enormous and rapid change, content to know that the scale still numbers 12 half steps and concert A is 440 (p. V). If the author did not know Kaplan's statement was from 1966, he might have thought it was a commentary on current music education practices. The emphatic statement resonates daily. How do we address issues in public education, generally, and music education, specifically, when we acknowledge that music is part of our lives in different ways and serves different purposes (Väkevä \& Westerlund, 2007).

\section{Engagement}

For decades, it has been widely agreed that engagement in schools refers to students' behaviors with which they intensely apply themselves to learning. Attributes of students' willingness and desire to participate play a role, but contemporary perspectives on engagement in school include students' abilities to persevere through challenges over sustained periods of time (Fletcher, 2015; Loveless, 2015; National Survey of Student Engagement [NSSE], 2013; Strong, Silver, \& Robinson, 1995). Fletcher (2015) added that successful educators are the ones who create conditions within classrooms that allow opportunities for students to engage. Through academic challenges, rigor, collaborative activities, and meaningful relationships and interactions with the teacher and adults, students are more likely to feel supported and will participate willingly in the learning activities.

Prominent scholar, Robert Marzano, is likely a familiar name in schools across the country. His published works include Art and Science of Teaching (2007) ${ }^{1}$. During the 2015-2016 school years, the author had the opportunity to participate directly in various Marzano workshops as part of his school district professional development. During these workshops throughout the year, he had opportunities to reflect on his teaching practices, as usual, but with new lenses of approaching contemporary classrooms. If these practices yield positive results in general classrooms, how might the author's strategies in the music room reflect new approaches and how might they be stuck in traditional methods?

From the teaching and learning perspective, an impacting component of the Marzano and Associates research has been around student engagement for learning. The author identifies three Marzano strategies and the use of these in his large ensemble classes. A former middle school student, Dailey, provides examples, in retrospect, of how these strategies were implemented and realized within the band class.

\footnotetext{
${ }^{1}$ Other Marzano titles include the New Art and Science of Teaching (2017), School Leadership That Works (2006, with Waters \& McNulty), and What Works in Schools (2003).
} 


\section{Physical Movement}

An argument could likely be made that playing wind, percussion, and stringed instruments is itself a physical activity. There are other ways throughout the week to get students to move differently, engaging more muscles and enhancing greater blood flow. To disrupt daily courses of action and stagnancy that can ensue from such routine, the author intends to have students move to various areas in the room and to other parts of the building. The small amount time to get elsewhere and to set up and organize within small groups changes the pace, briefly requires full body engagement, and contributes to collaboration and problem solving. Breaking up the large ensemble by encouraging both like and unalike groupings to practice at various spaces within the room not only involves the act of moving, getting students out of the chairs, but it also adds to the students' autonomy over how and where they engage in their student-led practice (Kooistra, 2016).

Dailey reflected on ways that physical movement was promoted through sectionals and student-led time during class. Sectional rehearsals are not uncommon. However, even sectionals tend to be highly teacher directed. The author's weekly "Wednesday split" is the opportunity for students to decide where they go, whom they go with, and what their area of practice will be. For readers unfamiliar with sectional rehearsals, Dailey describes this as "when you get up from your chair and go play with your section of instrument in another space, often concealed from the main practice room." We are fortunate to have various nooks and crannies. Students utilize the main room, the instrument storage room, an identified practice room, a space that formerly served as an amplitude modulation (AM) radio station, and even the building foyer. It is easy to say that the multiple sections utilize many spaces of the building of which the music room is a part. Sometimes, a smaller section would even practice in the music office. While happened, according to Dailey, the teacher would usually be helping other students with difficult parts of the music we were working on.

\section{Demonstrate Enthusiasm for Content}

Tone, demeanor, and exaggerated behaviors enhance critical situations and content areas. Good and Brophy clarified that this intense enthusiasm refers to teachers' means to identify why, to state their reasons as interesting, and emphasize the importance of the topic. They add that enthusiasm does not equate to pep talks or unnecessary theatrics (as cite in Marzano, 2007, p. 113). As a teacher, the attempts to be enthusiastic and extensive in the teaching/learning dynamic have been identified by Dailey in this way:

My band teacher has been the most enthusiastic teacher I have ever had. He always seems eager to learn new things, even though he is the one who teaching us the new things. He is very interested in music and clearly loves his job. It is very important to have an enthusiastic, eager learning teacher, because it makes the whole learning environment so much better. He always takes the time to talk about the music we are playing, like making sure we know how it should sound and the history of the song. I knew he was interested in what we were doing by the way he walked into class every day. He had the biggest smile and was always kind and caring to every student. I do not know how he did it, but he made us actually want to learn more and more about music and its culture.

Other students acknowledged their perception of the enthusiasm, mostly through physical gestures during rehearsal times. From smiling to verbal responses of "Yes!” to standing on the chair (stool), these actions were interpreted as expressions of the enthusiasm of the content. Trends in the responses were that the author is animated "always energetic" and "very positive."

Beyond this, some students responded that the level of enthusiasm gives them "energy to play" and motivates some "to do better and work harder." One student added that, "Because of Viar being enthusiastic, 
we are able to play good songs" and another added, "While he is enthusiastic it is fun to play, because it is very exciting and gives me more enjoyment of performing."

\section{Inconsequential Competition/Mild Pressure}

Competition with minimal or no rewards - the author generally no longer a proponent of competition in the music setting. However, there can be benefits. He believes Marzano's recommendation of inconsequential competition is realized by mild pressure, another engagement strategy. By having individuals, sections, small groupings, and combos play for each other within the large ensemble setting, students are likely to experience a sort of camaraderie that is supportive, but also the pressure of performing in front of one's peers is an example of forced attention (Marzano, 2007, p. 102).

Dailey adds that competition usually means striving for first place. In her class setting, however, it is intended to be about improving. From Dailey's perspective, the class never focused on being first only "on our own strengths and how we could make the band better by working together" with these strengths. She continued,

We always competed against ourselves, trying hard to improve and get better as each day passed. Although a little healthy competition against other bands is a good thing, our bands are generally just happy to be playing and having the opportunities, whether in a competitive setting or not.

Furthermore, according to Dailey, by playing in our combos, "We would take note of other combos if they were playing really well but we also were impressed and happy for them." The incorporation of combos, as well as the occasional competition, were not to be number one, but to encourage self- and group- improvement, and to want to improve the band overall. All band classes at our school had strong connections to each other, so we were happy with our improvement as a group, whether or not we were in formal competition.

In an open invitation to current students to participate in a questionnaire about their experiences, this topic of competition elicited the most discrepant responses. It was generally acknowledged that, as the teacher, the author does not encourage or focus on competition. However, there were different levels of student thoughts about it. For example, some noticed the teacher's interest to "encourage us to be the best we could possibly be and help us for the future," "supportive and fun and not too obsessed with competing for the band," and "more focused with everybody doing their best and helping everybody else to get better." However, there were a few responses that suggest the teacher should analyze and reconsider to meet those whose motivations are more competitively driven. One student feels that there is not competition to move up and get better parts, because "people who do not deserve the parts can just take them.” While the author has a rebuttal to this, he does think it warrants deep consideration and is something he will address for future planning. Likewise, others who felt the lack of focus on competition, both internally among each other and externally against other groups, results in individuals not feeling a need to practice as much.

\section{Importance of Engagement}

The results of the NSSE (2013) in mathematics suggest that self-reported high engagement is not an indicator for high achievement. However, high engagement is an indicator for school connection. Students who are engaged in the school process are more likely to stay in school, are more likely to learn skills around problem solving, and are more likely to acknowledge a sense of belonging to the school community. These positive factors contribute to higher graduation rates and generally higher grades. Low engagement tends to be 
prevalent in higher poverty communities, increasingly evident as students move through the system and into higher-grade levels (Fredricks et al, 2011).

\section{Relevance of Engagement to Instrumental Music Education}

As stated earlier, the author has participated in various workshops operated by Marzano and Associates, with foci on engagement and effective instruction and meaningful assessments for student achievement. The author's evolving position on music education and the way he structure his classes for heightened student engagement have been shaped by professional experiences, conflicting philosophies of music education, and by pragmatic necessity for program existence within the school. He suggests that a particular axiology is inherent to the program design, placing importance on new strategies for a changing sociology, and including student reflections on ways engagement strategies are implemented in the band class. Generally, acknowledged axiology refers to the role of an individual's values to his study or process; specifically, being cognizant of the ways these values influence the development, process, or conclusion to a study or implemented operational process (Tomar, 2014; Hesse-Biber, 2010; Engle, 2009; Ponterotto, 2005).

\section{Paraxial Music Education}

Elliott (2005) and Elliott and Silverman (2012) promoted the idea of music praxialism, one based in music action rather than aesthetic reception. The ways we do music education deserve fresh approaches to engage students in ways that may attract more participants, to provide academic support, and to address and reinforce concepts of music within unique contexts. Music is situational. With over six million students enrolled in California public schools ${ }^{2}$, a philosophy on music education must consider the many avenues to engage students. As such, a praxial approach to music education must have a place in our professional practices.

Elliott (2005) and Elliott and Silverman's (2012) worked around praxial music education, with its acknowledgment of societal pluralism, has influenced the author's teaching practice. This work has caused the author to plan for actions that include deviations from aesthetic-centric practices in his ensemble-based classes. Using the band as the formal organization of students to create class period X, the author's growth has been to honor the standard elements and methods of tone production, intonation, balance, blend, and understanding of notation while also strategizing to provide individuals time during our class periods to explore personal interests, tutor each other, and to co-create through performing and/or writing. While the former provides a foundation of technical proficiency to engage in formal music-making with a common language, the latter provides opportunities for individuals to self-direct toward addressing the four Cs-collaborate, communicate, create, and think critically of 21st century learning ${ }^{3}$. Teachers should approach the band with different foci and strategies, and it is acceptable that outcomes are different.

Mantie (2012) criticized the structure of school bands for its evolved design over time toward specific musicality to the exclusion of alternatives. The author believes this plays a role in students' interests in performing, but it affects us on a larger scale for administrative review. Currently, students must be considered for their growth potential as a band student and not for the interpersonal enjoyment through the participation. The sentiment continues to be explored, as evidenced by Gibson's study (2016), which identified that band

\footnotetext{
${ }^{2}$ According to the California Department of Education Website, CalEd Facts reported 6,226,737 students enrolled in the state's public schools during the 2015-2016 school years in kindergarten to Grade 12 (K-12), including ungraded programs.

${ }^{3}$ Retrieved from http://www.nea.org/assets/docs/A-Guide-to-Four-Cs.pdf.
} 
teachers, in general, were not doing enough to engage students in the band activity (p. 35), resulting in increased attrition, especially at the middle school level.

What does this have to do with the idea of engagement and a practical approach to the classroom today? Schewe (2016) reminded us that phenomena, like engagement, are changing states of being and are affected by various environments. She continues that the development of engagement strategies should be goals toward the motivation of students. Marzano (2007) encouraged action steps to promote physical activity, to challenge students' thinking, and to stimulate attention. Although the author has not polled his colleagues, he believes many of them would say they facilitate these actions within their large ensembles seated in standard formats. However, the large ensemble is not the only means of teaching and learning, and in some scholarly writing, it is now suggested that the focus of large ensemble instruction is detrimental to individual musicianship and growth, hence to the music education profession (Kooistra, 2016; Mantie, 2012). This article is not going to defend or deny such position. However, this may be an example of the unsettling condition suggested by Elliott and Silverman (2012).

\section{Conclusion}

Over the years, different words have been used when referring to students' on task behaviors. The author likes to think of our current trend toward engagement to mean not only that students are task-doing, but that they are fully and actively engaged with their own learning. Having been in the profession for a good amount of time, the author has encountered, time and time again, colleagues who opine that strategies of the day are not intended for or useful in the band room. He encourages any colleague who feels this way to acknowledge everyone's evolution, including ours in the band room, and try reaching students in ways that may seem different. In most cases, that will be the point. As Reeve (Marzano, 2007) suggested 10 years ago, when engagement is characterized by the full range of on-task behavior, positive emotions, invested cognition, and personal voice, it functions as the engine for learning and development (p. 99).

\section{References}

Elliott, D. (Ed.). (2005). Introduction. In Praxial music education: Reflections and dialogues (pp. 3-18). New York, N.Y.: Oxford University Press.

Elliott, D., \& Silverman, M. (2012). Rethinking philosophy, re-viewing musical-emotional experiences. In W. Bowman, \& A. Frega (Eds.), The Oxford handbook of philosophy in music education (pp. 37-62). New York, N.Y.: Oxford University Press.

Engle, E. (2009). Ontology, epistemology, axiology: Bases for a comprehensive theory of law. Appalachian Journal of Law, 8(1), 103-122. Retrieved June 4, 2016, from http://papers.ssrn.com/sol3/papers.cfm?abstract_id=1268528

Fletcher, A. (2015). Defining student engagement: A literature review. Retrieved March 11, 2017, from https://soundout. org/defining-student-engagement-a-literature-review/

Fredricks, J., McColskey, W., Meli, J., Mordica, J., Montrosse, B., \& Mooney, K. (2011). Measuring student engagement in upper elementary through high school: A description of 21 instruments. In Issues \& Answers Report (REL 2011, No. 098). Washington, D.C.: U.S. Department of Education. Retrieved from http://ies.ed.gov/ncee/edlabs

Gibson, A. (2016). Students' perceptions of high school band programs, their marching bands, and factors at lead to intended enrollment in these ensembles (Ph.D. dissertation, Georgia State University). Retrieved from http://scholarworks. gsu.edu/cgi/viewcontent.cgi?article=1018\&context=mse_diss

Hesse-Biber, S. (2010). Feminist approaches to mixed methods research: Linking theory and praxis. In A. Tashakkori, \& C. Teddlie (Eds.) Sage handbook of mixed methods in social \& behavioral research (pp. 169-192). Thousand Oaks: Sage Publications, Inc..

Kaplan, M. (1966). Foundations and frontiers of music education. New York, N.Y.: Holt, Rinehart, and Winston, Inc.. 
Kooistra, L. (2016). Information music education: The nature of a young child's engagement in an individual piano lesson setting. Research Studies in Music Education, 38(1), 115-129. DOI: 10.1177/1321103X15609800

Loveless, T. (2015). How well are American students learning? The 2015 Brown Center Report on American Education, 3(4), 26-36. Retrieved March 11, 2017, from https://www.brookings.edu/research/student-engagement/

Mantie, R. (2012). Striking up the band: Music education through a foucaultian lens. Action, Criticism, \& Theory for Music Education, 11(1), 99-123.

Marzano, R. (2007). The art and science of teaching. Alexandria, V.A.: Association for Supervision and Curriculum Development.

Mt. Diablo Unified School District (MDUSD). (n.d.). California school climate, health, and learning survey. Retrieved from http://www.mdusd.org/calhealthykids

National Survey of Student Engagement (NSSE). (2013). A fresh look at student engagement-Annual results 2013. Bloomington, I.N.: Indiana University Center for Postsecondary Research. Retrieved March 11, 2017, from http://nsse.indiana. edu/NSSE_2013_Results/pdf/NSSE_2013_Annual_Results.pdf

Ponterotto, J. (2005). Qualitative research in counseling psychology: A primer on research paradigms and philosophy of science. Journal of Counseling Psychology, 52(2), 126-136. DOI: 10.1037/0022-0167.52.2.126

Schewe, A. (2016). Making student engagement visible: Using self-determination theory to examine how two social studies teachers support students' needs for autonomy, competence, and relatedness (Ph.D. dissertation, Georgia State University). Retrieved from http://scholarworks.gsu.edu/mse_diss/28

Strong, R., Silver, H., \& Robinson, A. (1995). Strengthening student engagement: What do students want. In Education leadership (Vol. 95, pp. 8-12). Retrieved March 11, 2017, from http://www.ascd.org/publications/educational-leadership/ sept95/vol53/num01/Strengthening-Student-Engagement@-What-Do-Students-Want.aspx

Tomar, B. (2014). Axiology in teacher education: Implementation and challenges. IOSR Journal of Research \& Method in Education, 4(2), 51-54. Retrieved from http://www.iosrjournals.org/iosr-jrme/papers/Vol-4\%20Issue-2/Version-3/H0423515 4.pdf

Väkevä, L., \& Westerlund, H. (2007). The method of democracy in music education. Action, Criticism, \& Theory for Music Education, 6(4), 96-108. Retrieved from http://act.maydaygroup.org/articles/Väkevä_Westerlund6_4.pdf

West Branch Community Schools. (2017). The school cliff: Student engagement drops with each school year. Retrieved from http://www.west-branch.k12.ia.us/the-school-cliff-student-engagement-drops-with-each-school-year/ 